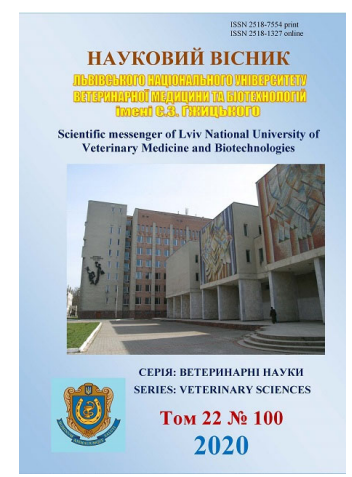

Науковий вісник Львівського національного університету ветеринарної медицини та біотехнологій імені С.3. Гжицького. Серія: Ветеринарні науки

\author{
Scientific Messenger of Lviv National University \\ of Veterinary Medicine and Biotechnologies. \\ Series: Veterinary sciences
}

doi: 10.32718/nvlvet10019

https://nvlvet.com.ua/index.php/journal

UDC 339.543.012.42:338.43 (477)

\title{
Reforming of legislation on the residues of veterinary medicinal products in foodstuffs of animal origin as a component of Ukraine food security
}

\section{Berezovska}

Taras Shevchenko National University of Kyiv, Ukraine

Article info

Received 16.10.2020

Received in revised form 17.11 .2020

Accepted 18.11.2020

Taras Shevchenko National University of Kyiv,

Volodymyrska Str., 60 Kyiv, 01033, Ukraine. Tel.: +38-050-330-21-90 E-mail:bav13@meta.ua
Berezovska, I. (2020). Reforming of legislation on the residues of veterinary medicinal products in foodstuffs of animal origin as a component of Ukraine food security. Scientific Messenger of Lviv National University of Veterinary Medicine and Biotechnologies. Series: Veterinary sciences, 22(100), 108-115. doi: 10.32718/nvlvet10019

It is known that the food security of the state, aimed at providing the population with quality and healthy food, is an important component of economic security. Recent developments in the world and national security challenges posed by the Covid-19 virus pandemic necessitate a reassessment of approaches to the legal regulation of issues that significantly affect human health. Today, the reform of the relevant national legislation on FAR residues in food requires a systematic and holistic approach and the definition of its priorities in such a way as to promote food safety and the development of domestic business. The article is devoted to the analysis of the current Ukraine legislation concerning regulation of residues of veterinary medicinal products in foodstuffs of animal origin. It was shown that the formation of such legislation was due to the development of international trade, including the fulfilment of the European Union requirements for the safety of foodstuffs imported into its market. At the same time, the conclusion of the Association Agreement and the introduction of a Free trade zone with the EU was a significant impetus to the reforming of national legislation on residues. The analysis of EU regulations, which serves as a legal basis for the residues control at the EU level, was carried out. It is noted that today in the Ukrainian legislation, despite the introduction of annual national plans for state monitoring of residues of veterinary medicinal products and contaminants in live animals and unprocessed foodstuffs of animal origin, there are a number of gaps that require urgent legislative regulation. It was proved that the completion of the reform of the national legislation on residues will contribute to improving safety of domestic foodstuffs, and therefore, will have important positive consequences not only for the development of trade with the EU, but primarily for the food security of Ukraine and the protection of the health of Ukrainian citizens.

Key words: European Union, Association Agreement, regulation, veterinary medicinal products, harmonization of legislation, residues of active substances (pharmacologically active substances), maximum residue limit (MRL).

\section{Реформування законодавства щодо залишків ветеринарних препаратів у харчових продуктах тваринного походження як складова продовольчої безпеки України}

\author{
І. А. Березовська
}

Київський національний університет імені Тараса Шевченка, м. Київ, Украӥна

Як відомо, продовольча безпека держави, націлена на забезпечення населення якісними і корисними для здоров'я продуктами харчування, є важливою складовою частиною економічної безпеки. Останні події в світі та виклики національній безпеці, спричинені пандемією вірусної хвороби Соvіd-19, зумовлюють необхідність переочінки підходів до правового регулювання питань, щяо істотно впливають на здоров'я людей. На сьогодні реформування відповідного національного законодавства щзодо залишків ФАР у продуктах харчування потребує системного та иілісного підходу і визначення його пріоритетів таким чином, щзоб сприяти під- 
вищенню безпеки харчових продуктів та розвитку вітчизняного бізнесу. Статтю присвячено аналізу чинного законодавства України щуодо регулювання залишків ветеринарних препаратів у харчових продуктах тваринного походження. Продемонстровано, щчо становлення такого законодавства було зумовлене розвитком міжнародної торгівлі, зокрема виконанням вимог Свросоюзу щзодо безпечності харчової продукиії, щуо імпортується на його ринок. При цььму вагомим поштовхом до реформування національного законодавства про залишки стало укладання Угоди про асоиіацію та запровадження зони вільної торгівлі з СС. Здійснено аналіз регламентів ЄС, щзо служать правовою основою для регулювання залишків на рівні Свросоюзу. Відзначено, шчо на сьогодні в законодавстві Украӥни, незважаючи на запровадженням щорічних начіональних планів державного моніторингу залишків ветеринарних препаратів та забруднювачів у живих тваринах і необроблених харчових продуктах тваринного походження, залишається низка прогалин, щчо потребують нагального законодавчого врегулювання. Доведено, щчо завершення реформи національного законодавства щодо залишків сприятиме підвищенню безпеки вітчизняної харчової продукцї, а отже матиме важливі позитивні наслідки не тільки для розвитку торгівлі з СС, а передусім - для продовольчої безпеки держави та захисту здоров'я украӥнських громадян.

Ключові слова: Свропейський Союз, Угода про асочіаџію, регламент, ветеринарні препарати, гармонізація законодавства, залишки діючих речовин (фармакологічно активних речовин), максимальна межа залишків (MRL).

\section{Вступ}

Як відомо, продовольча безпека держави, націлена на забезпечення населення якісними і корисними для здоров'я продуктами харчування, $є$ важливою складовою частиною економічної безпеки. Останні події в світі та виклики національній безпеці, спричинені пандемією вірусної хвороби Covid-19, зумовлюють необхідність переоцінки підходів до правового регулювання питань, що істотно впливають на здоров'я людей. На жаль, сьогодні, за оцінками більшості науковців, рівень продовольчої безпеки України $є$ вкрай низьким. Тривалий час, незважаючи на очевидну актуальність проблем продовольчої безпеки держави, українське законодавство не врегульовувало низку їі суттєвих складових. Серед них питання залишків ветеринарних препаратів у харчових продуктах тваринного походження. Точніше - йдеться про залишки так званих “фармакологічно активних речовин”, або “діючих речовин” (ДР), які внаслідок застосування тваринам ветеринарних препаратів 3'являються у харчових продуктах тваринного походження, призначених для споживання людиною: молоко, м'ясо, риба, молюски і ракоподібні, яйця, мед, їхні похідні та інші продукти, виготовлені з частин тварин, окремих їх органів та/або тканин.

3 урахуванням постійно зростаючого обсягу застосування ветеринарних препаратів та зокрема антибіотиків та гормонів у сучасному тваринництві, проблема їх шкідливості для людей набула особливої актуальності у всьому світі. Більшість таких препаратів $є$ потенційно небезпечними, якщо не використовуються відповідно до призначення. Фактор появи резистентності до антибіотиків, що тягне неможливість лікування людей та тварин від особливо тяжких хвороб, змушує розвинуті країни встановлювати законодавчі вимоги до рівнів залишків. Нагальна потреба у створенні механізмів захисту здоров'я людей і тварин, навколишнього середовища від ризиків, пов'язаних із застосуванням ветеринарних препаратів, поступово стає все очевиднішою. На міжнародному рівні це призвело до затвердження під керівництвом ФАО/ВООЗ Кодексу Аліментаріус, який серед іншого містить міжнародні стандарти щодо максимальних меж залишків низки ДР. Найбільш дієве законодавство щодо залишків ветеринарних препаратів, спрямоване на досягнення найвищого в світі рівня безпеки харчової продукції, було розроблено на рівні Свросоюзу. На сьогодні законодавство, що регулює залишки ветеринарних препаратів (Residues of veterinary medicinal products), складає окремий правовий інститут харчового права $€ C$ (EU food law).

Внаслідок укладання Угоди про асоціацію з Свропейським Союзом (УА) (Uhoda pro asotsiatsiiu mizh Ukrainoiu ta Yevropeiskym Soiuzom) Україна в обмін на доступ до європейського ринку зобов'язалась здійснити масштабне реформування вітчизняного законодавства про безпеку харчових продуктів 3 метою його наближення до відповідного законодавства ЄС. Протягом останніх років внаслідок виконання УА були здійснені вагомі кроки, спрямовані на запровадження в країні гармонізованого з СС законодавства про харчову безпеку. 3 квітня 2020 року вперше в історії України почали діяти Максимальні межі (рівні) залишків діючих речовин ветеринарних препаратів у харчових продуктах тваринного походження, затверджені Наказом Міністерства охорони здоров'я (Nakaz Ministerstva okhorony zdorovia Ukrainy). Однак в українському законодавстві досі залишаються неврегульованими базові засади визначення та контролю залишків, що негативно впливає, з одного боку, на безпеку здоров'я громадян, з іншого - на ведення вітчизняного бізнесу, зокрема, пов'язаного з виробництвом та експортом тваринницької продукції та виробництвом ветеринарних препаратів.

На сьогодні реформування відповідного національного законодавства щодо залишків ФАР у продуктах харчування потребує системного та цілісного підходу і визначення його пріоритетів таким чином, щоб сприяти підвищенню безпеки харчових продуктів та розвитку вітчизняного бізнесу.

Аналіз останніх досліджень і публікацій. У вітчизняній доктрині питання гармонізації окремих аспектів харчового та фітосанітарного законодавства України iз законодавством $Є С$ досліджуються в роботах С. Бугери, Я. Добідовської, В. Єрмоленка, Т. Коваленко, Л. Кричковської, В. Мамутова, Т. Чурилової. Результати досліджень теоретичних та практичних аспектів продовольчої безпеки подано в роботах науковців Н. Волченко, М. Кіржецької, Ю. Кіржецького, Р. Кузьо, В. Липчука та інших. Окремі питання моніторингу залишків ветеринарних препаратів у харчових продуктах висвітлюються в роботах О. Байєр, Ю. Новожицької, Л. Шевченко, В. Михальської, 
В. Салати, М. Кухтина. Водночас спеціальні роботи, присвячені реформуванню законодавства України щодо залишків ветеринарних препаратів в продуктах харчування, поки що відсутні.

Метою цієї роботи $є$ комплексний аналіз стану правового регулювання залишків ДР ветеринарних препаратів у харчових продуктах в законодавстві Україні та визначення напрямків його подальшої гармонізації із законодавством ЄС. В рамках цієї статті питання правового регулювання інших видів залишків, зокрема пестицидів, не досліджуються.

\section{Результати та їх обговорення}

Характеризуючи розвиток вітчизняного законодавства щодо залишків, варто зазначити, що він зумовлений не стільки державною політикою щодо захисту здоров'я громадян, скільки розвитком експорту та вимогами інших країн щодо стандартів безпеки харчової продукції. Становлення законодавства щодо залишків в Україні безпосередньо пов'язане з посиленням міжнародних торговельних відносин, зокрема зі вступом України до Світової організації торгівлі.

Так, у 2008 році у профільний Закон "Про ветеринарну медицину" вперше було винесено законодавче визначення поняття "максимальна межа залишків" (максимально допустимий рівень залишків) максимально допустимий вміст діючої речовини ветеринарних препаратів та їх метаболітів (продуктів перетворення в живих системах) і токсикантів у живих тваринах, неїстівних продуктах тваринного походження та кормах, перевищення якого може негативно вплинути на здоров'я тварин та людей, що встановлюється ветеринарно-санітарними заходами або, якщо таких показників у заходах не існує, встановлюється на рівнях, рекомендованих відповідними міжнародними організаціями (Zakon Ukrainy "Pro veterynarnu medytsynu").

Одночасно було доповнено й статтю 67 цього Закону, яка регулює обіг ветеринарних препаратів, пунктом 7 такого змісту: “максимальна межа залишків ветеринарних препаратів у необроблених харчових продуктах тваринного походження, які пригнічують функцію залоз внутрішньої секреції тварин (зокрема мають тиреостатичну, естрогенну, андрогенну і гестагенну дію, а також антибіотики та гормони), не може перевищувати максимальну межу залишків, встановлену Комісією з Кодексу Аліментаріус. Якщо максимальна межа залишків, встановлена Україною, перевищує стандарти зазначеного Кодексу або відповідний стандарт Комісії з Кодексу Аліментаріус не розроблено, Україна надає на запит країни - члена СОТ відповідну оцінку ризику”.

Зазначена норма 3 посиланням лише на кодекс Аліментаріус досі служить основим правовим джерелом зобов'язання контролювати залишки ветеринарних препаратів у харчових продуктах тваринного походження в законодавстві України.

Наступний етап становлення законодавства про залишки був зумовлений розвитком торгівлі з СС. Зокрема, найдієвішим стимулом для такого розвитку стала правова норма, закріплена в ст. 29 Директиви 96/23/ЕС стосовно вимог до імпорту тваринницької продукції з третіх країн (Council Directive 96/23/EC of 29 April 1996). Вона передбачає, що умовою дозволу на імпорт до СС живих тварин та тваринницької продукції з третьої країни $є$ подання такою третьою країною плану, який встановлює гарантії щодо моніторингу груп залишків та речовин, згаданих у Додатку I до Директиви. Серед іншого у вказаному Додатку міститься група В - Ветеринарні препарати та забруднювачі, яка зокрема включає: 1) всі антибактеріальні речовини, включаючи сульфономіди, хінолони, 2) інші ветеринарні препарати (антигельмінтики, антикокцидні препарати, включаючи нітроімідазоли, карбамати та піретроїди, седативні засоби, нестероїдні протизапальні засоби, інші фармакологічно активні речовини, 3) інші речовини та забруднювачі навколишнього середовища.

Виконанням цієї вимоги було зумовлене прийняття у 2009 році спеціального Закону "Про Загальнодержавну цільову економічну програму проведення моніторингу залишків ветеринарних препаратів та забруднюючих речовин у живих тваринах, продуктах тваринного походження і кормах, а також у харчових продуктах, підконтрольних ветеринарній службі, на 2010-2015 роки" (Zakonu Ukrainy "Pro Zahalnoderzhavnu tsilovu ekonomichnu prohramu..., 2009).

Зазначений закон визначив завдання i заходи, спрямовані на виконання програми проведення державного моніторингу залишків ветеринарних препаратів та забруднюючих речовин у живих тваринах, продуктах тваринного походження і кормах, а також у харчових продуктах, підконтрольних ветеринарній службі, спрямовані зокрема на створення матеріально-технічної бази для виконання плану моніторингу, підтвердження професійного рівня фахівців, залучених до виконання плану моніторингу, розроблення підтверджуваних методик контролю за залишками, формування системи проведення моніторингу залишків та безпосереднє виконання щорічного плану державного моніторингу.

Саме завдяки реалізації передбачених вказаним законом заходів та проведенню необхідної підготовчої роботи при постійному впливі з боку Свросоюзу (зокрема, на виконання вже згаданої Директиви 96/23 та Рішення Комісії СС №2011/163/EU від 16 березня 2011 р. про затвердження планів, представлених третіми країнами відповідно до Статті 29 Директиви Ради 96/23), починаючи з 2016 року в Україні почали затверджуватись та виконуватись щорічні національні Плани державного моніторингу залишків ветеринарних препаратів та забруднювачів у живих тваринах $\mathrm{i}$ необроблених харчових продуктах тваринного походження. Зокрема, затверджений Наказом Держпродспоживслужби план моніторингу залишків на поточний 2020 рік (Nakaz Derzhprodspozhyvsluzhby) передбачає здійснення моніторингу залишків ветеринарних препаратів та забруднювачів, визначених у Додатку I Директиви 96/23 щодо таких видів харчової продукції, як яловичина, свинина, м'ясо птиці, м'ясо індиків, аквакультура (риба), молоко, курячі яйця, м’ясо кро- 
лів та мед. Крім переліку речовин щодо яких здійснюється контроль. План моніторингу визначає методи контролю та допустимі при контролі межі, а також уповноважені на проведення контролю лабораторії. Запровадження системи державного моніторингу залишків стало без перебільшення революційним кроком, який підняв стандарти контролю залишків на вищий рівень та дозволив українським виробникам тваринницької продукції вийти на ринок ЄС.

3 цього моменту дієвим стимулом для реформування законодавства про залишки стає функціонування зони вільної торгівлі з Євросоюзом. Враховуючи експортний потенціал українських виробників харчової продукції тваринного походження, закономірною стала особлива увага європейської сторони до питань правового регулювання залишків в Україні. I хоча це питання окремо не загадується в Угоді про асоціацію, воно підпадає під механізми співпраці, що вироблені в рамках глави 4 Санітарні та фітосанітарні заходи Розділу 4 УА “Торгівля та питання, пов'язані і з торгівлею" (Uhoda pro asotsiatsiiu mizh Ukrainoiu ta Yevropeiskym Soiuzom).

Так, на основі УА органи Свросоюзу почали моніторити процес виконання Україною зобов'язань щодо наближення національного до законодавства Свросоюзу, зокрема проводити аудити національних процедур. Одним з перших аудитів після підписання УА стала робота місії Food and Veterinary Office Генерального директорату Охорони здоров'я та харчової безпеки Сврокомісії (DG SANTE), яка у вересні 2016 року перевіряла питання здійснення в Україні контролю за залишками ветеринарних препаратів та забруднюючих речовин у продуктах тваринного походження (V Ukraini rozpochala robotu misiia YeK). За результатами проведеної місією перевірки прийнято Підсумковий звіт аудиту, що містить висновки та рекомендації для національних компетентних органів, зокрема й щодо залишків (Final report of an audit carried out in Ukraine).

Реалізуючи зобов'язання за УА, попри низку складнощів та затримок, Україні протягом 2014-2017 року вдалося досягнути вагомого прогресу в реформі законодавства у сфері харчової безпеки. Безумовними досягненнями стало прийняття гармонізованих з вимогами СС базових законопроектів про основні принципи і вимоги до безпечності та якості харчових продуктів, про державний контроль за дотриманням законодавства про харчові продукти, корми, побічні продукти тваринного походження, здоров'я та благополуччя тварин, а також про безпечність та гігієну кормів (Zakon Ukrainy Pro osnovni pryntsypy..., 1997; Zakon Ukrainy Pro derzhavnyi kontrol..., 2017; Zakon Ukrainy Pro bezpechnist ta hihiienu kormiv, 2017).

Щодо регулювання залишків відповідно до затвердженої Кабінетом міністрів України Всеохоплюючої стратегії імплементації Глави IV (пункт 62 Розділу 2 “'Здоров’я тварин”) (Rozporiadzhennia Kabinetu Ministriv Ukrainy vid 24 liutoho 2016) до переліку актів Свросоюзу, що мають бути впроваджені у вітчизняне законодавство, входять обидва базові правові акти СС щодо залишків: 1) Регламент Свропейського Парла- менту та Ради (СС) № 470/2009 від 6 травня 2009 р., яким встановлюються процедури Співтовариства 3 визначення рівнів залишків фармакологічно активних речовин у харчових продуктах тваринного походження та скасовується дія Регламенту Ради (СЕС) № 2377/90 і вносяться зміни до Директиви Європейського Парламенту та Ради 2001/82/СС і Регламенту Свропейського Парламенту та Ради (СС) № 726/2004 (Rehlament Yevropeiskoho Parlamentu ta Rady (IeS) № 470/2009), а також 2) Регламент Свропейського Парламенту та Ради (СС) № 37/2010 від 22 грудня 2009 р. щодо максимальних меж залишків фармакологічно активних речовин та їх класифікації в харчових продуктах тваринного походження (Rehlament Yevropeiskoho Parlamentu ta Rady (IeS) № 37/2010).

Наразі ці Регламенти служать правовою основою для регулювання залишків ДР у харчових продуктах тваринного походження в усіх державах-членах СС. Крім того, вони служать основою для оцінки еквівалентності підходів до безпечності харчової продукції, що імпортується на ринок $Є С$ зретіх країн.

Аналіз зазначених Регламентів свідчить, що в усіх країнах Євросоюзу діє уніфікований підхід до класифікації залишків ДР у харчових продуктах тваринного походження, а також визначено однакові максимально допустимі межі ДР. У поєднанні з відповідними положеннями базової для ветеринарних препаратів Директиви Свропейського Парламенту та Ради про Кодекс Співтовариства щодо лікарських засобів для ветеринарного застосування № 2001/82/СС від 6 листопада 2001 року (Dyrektyva Yevropeiskoho Parlamentu ta Rady..., 2001), ці документи визначають чіткий порядок реєстрації, виробництва, обігу та контролю за використанням ветеринарних препаратів в Свросоюзі, спрямований на забезпечення їх максимально нешкідливого впливу на здоров'я людей.

Зокрема, в ст. 2 Регламенту 470/2009 наводиться визначення поняття “залишки фармацевтично активних речовин” (англ. residues of pharmacologically active substances) яким позначаються всі фармакологічно активні речовини, виражені в мг/кг або мкг/кг на масу сирому вигляді: як активні й допоміжні речовини, так і продукти розпаду та їх метаболіти, що залишаються в продуктах харчування, отриманих $з$ тварин (Rehlament Yevropeiskoho Parlamentu ta Rady (IeS) № 470/2009).

Регламент також оперує поняттям "максимальних меж залишків" (англ. maximum residue limit - надалі MRL), яким позначається максимальна концентрація залишку ДР, що може бути дозволена в харчових продуктах тваринного походження. Окрема увага присвячена процедурі визначення рівня залишку ДР, що встановлюється 3 метою контролю у випадку, коли для окремих речовин не був визначений MRL, так звана "референтна точка для втручання" (англ. reference point for action).

Положення ст. 3 - 13 Регламенту № 470/2009 детально виписують порядок визначення максимальних меж залишків ДР, призначених для використання у ветеринарних препаратах, а також інших ДР, що можуть потребувати оцінки. 
Так, відповідно до ст. 3. Регламенту, будь-яка ДР, призначена на території ЄС для використання у ветеринарних препаратах для продуктивних тварин, потребує обов'язкового висновку Європейського Медичного Агентства (CMA) щодо MRL, сформульованого Постійним Комітетом 3 ветеринарних препаратів, діяльність якого передбачена цим Регламентом. Такий висновок підлягає офіційному опублікуванню (ст. 12) і повинен включати в себе наукові рекомендації щодо оцінки ризику й управління ризиком (ст. 5).

У разі відсутності висновку СМА для будь-якої ДР претендент на отримання реєстраційного свідоцтва на ветеринарний препарат, в якому використовується така речовина, повинен для отримання висновку подати заявку відповідно до ст. 8 Регламенту.

Базовою для розуміння підходів СС щодо залишків є ст. 14 Регламенту № 470/2009, що містить відповідну класифікація ДР (Rehlament Yevropeiskoho Parlamentu ta Rady (IeS) № 470/2009). Ïї положеннями передбачається, що відповідно до висновків СМА Комісія СC повинна класифікувати ДР щодо MRL. Така класифікація повинна включати список ДР із зазначенням терапевтичного класу їх приналежності, а також визначати щодо кожної речовини і за необхідності щодо певних харчових продуктів чи видів тварин один із таких показників: MRL; тимчасовий MRL; відсутність необхідності встановлення MRL; заборона на використання речовини.

Відповідно до ст.16 Регламенту в межах СС продуктивним тваринам можуть застосовуватись тільки ДР, що класифіковані згідно з вищезазначеною ст. 14 Регламенту № 470/2009. Це положення кореспондується $з$ раніше запровадженою нормою ст. 6 Директиви № 2001/82, за якою в СС не може бути зареєстровано ветеринарний препарат, якщо він застосовується до одного або кількох видів тварин, які використовуються для виробництва харчових продуктів, крім випадків, коли фармакологічно активні речовини, що входять до його складу, містяться в Додатках I, II або III до Регламенту (СЕС) № 2377/90.

Таким чином, усі ДР, що використовуються в СС для виробництва ветеринарних препаратів поділяються на групи: 1) такі, що не потребують встановлення максимальної межі залишків для захисту здоров'я людини (зокрема, рослинні, вітамінні та інші речовини); 2) речовини з визначеною максимальною межею залишків (визначається Комісією на виконання висновку СМА або рішення Комісії Кодексу Аліментаpiyc, прийнятого без заперечень з боку (С); 3) речовини з визначеною тимчасовою максимальною межею залишків (застосовується на період до 5 років у разі, коли наукові дані щодо речовини неповні, за умови, що немає підстав стверджувати, що залишки цієї речовини на запропонованому рівні становлять небезпеку для здоров'я людини); 4) речовини, застосування яких продуктивним тваринам забороняється (у разі загрози здоров'ю людини чи неможливості прийняття остаточного висновку про вплив на здоров'я людини залишку речовини.

На виконання вимог ст. 27 Регламенту № 470/2009 в грудні 2009 року Комісія прийняла Регламент
№ 37/2010, що об’єднує в алфавітному порядку перелік ДР і містить їх класифікацію щодо MRL, згідно 3 Додатками I-IV скасованого Регламенту № 2377/90. Відповідно до ст. 1 Регламенту № 37/2010 перелік та класифікація ДР щодо MRL викладені в Додатку до цього документа (Rehlament Yevropeiskoho Parlamentu ta Rady (IeS) № 37/2010).

Варто зазначити, що включена у вказаний Додаток таблиця 1 “Дозволені речовини” містить об'ємний перелік ДР, який чисельно значно перевищує кількість речовин, згаданих в Кодексі Аліментаріус, а також Таблицю 2 “Заборонені речовини” з переліком 10 найменувань ДР, використання яких продуктивним тваринам в СС заборонено.

Таким чином, на сьогодні правові засади регулювання залишків ветеринарних препаратів в СС визначаються положеннями Регламенту № 470/2009 (Rehlament Yevropeiskoho Parlamentu ta Rady (IeS) № 470/2009) та Регламенту № 37/2010 (Rehlament Yevropeiskoho Parlamentu ta Rady (IeS) № 37/2010). Зокрема, у відповідності з ними регулюється питання дозволу для використання будь-якої ДР у складі ветеринарного препарату та змісту документації для його реєстрації на території ЄС, в разі необхідності визначається MRL такої речовини у продуктах харчування тваринного походження, розраховується необхідний період каренції (виведення ДР з організму тварини) та здійснюється контроль фактичної відповідності виробленої харчової продукції встановленим вимогам щодо залишків. Окрім згаданих законодавчих актів, величезне значення має й діяльність компетентних органів. Роль масивного доробку висновків СМА щодо ДР, які деталізують та пояснюють особливості застосування конкретних показників до різних видів харчової продукції тваринного походження, важко переоцінити.

Повертаючись до аналізу українського законодавства, варто зазначити, що хоча відповідно до зобов'язань щодо УА кінцевим строком для впровадження вказаних регламентів СС в законодавство України було визначено 2018 рік, цей процес досі не завершено. Лише в грудні 2019 року Міністерство охорони здоров'я на виконання положень частини другої статті 6 Закону України "Про основні принципи та вимоги до безпечності та якості харчових продуктів" (Zakon Ukrainy Pro osnovni pryntsypy..., 1997) вперше офіційно затвердило Показники безпечності харчових продуктів “Максимальні межі (рівні) залишків діючих речовин ветеринарних препаратів у харчових продуктах тваринного походження" (Nakaz Ministerstva okhorony zdorovia Ukrainy), в основі яких по суті відображено показники, викладені у Регламентi № 37/2010 (Rehlament Yevropeiskoho Parlamentu ta Rady (IeS) № 37/2010).

За зразком вказаного регламенту в Таблиці 1 Показників в алфавітному порядку англійською мовою викладено діючі речовини, їх залишкові індикатори, зазначено види тварин та цільові тканини, за якими визначено відповідні MRL. B певних випадках зазначені застереження та терапевтична класифікація речовин. Таблиця 2 містить MRL діючих речовин кокци- 
діостатиків та гістомонстатиків, а Таблиця 3 - Заборонені ветеринарні препарати у харчових продуктах тваринного походження, MRL діючих речовин яких не можуть бути встановлені. Лише в примітках до вказаних таблиць міститься положення про те, що харчові продукти тваринного походження та/або інгредієнти тваринного походження не можуть перебувати в обігу, якщо вони містять залишки діючих речовин ветеринарних препаратів із перевищенням максимальних допустимих рівнів.

Довгоочікуване прийняття національних MRL безперечно є вагомим кроком для запровадження в Україні європейських стандартів регулювання залишків. Відтепер виробники ветеринарних препаратів та виробники харчової продукції отримали допустимі межі, при дотриманні яких їхня продукція офіційно визнається безпечною для здоров'я людей.

Однак, на нашу думку, сама лише транспозиція вказаних показників з права СС без запровадження комплексного національного законодавства та розвитку дієвого механізму оцінки безпечності харчових продуктів, очевидно, не створить реальних засад продовольчої безпеки України. По суті більшість базових принципів та процедур визначення залишків, передбачених Регламентом № 470/2009, досі відсутні в законодавстві України та потребують нагального законодавчого врегулювання. Тож для дієвого застосування затверджених нарешті Міністерством охорони здоров'я MRL має бути комплексно реформована нормативна база щодо обігу ветеринарних препаратів. Значною мірою існуючі прогалини в законодавстві можуть бути заповнені у разі прийняття проекту нового закону "Про ветеринарну медицину та благополуччя тварин”, що в квітні 2020 року був зареєстрований у Верховній Раді України за № 3318 (Proekt Zakonu pro veterynarnu medytsynu ta blahopoluchchia tvaryn).

Крім закріплення визначення поняття “максимальна межа залишків діючої речовини (активного фармацевтичного інгредієнту)", законопроект передбачає відповідно до прав ЄС норму про те, що державна реєстрація ветеринарного препарату, призначеного для продуктивних тварин, може бути здійснена лише за умови встановлення MRL діючих речовин, що входять до його складу, в порядку, визначеному Кабінетом Міністрів України (п. 4 ст. 55).

Базове значення для національної продовольчої безпеки матиме положення щодо порядку використання ветеринарних препаратів, закріплене в п. 5 ст. 79 законопроекту. Останні повинні застосовуватися у спосіб, що не допускає перевищення максимальних меж залишків ДР, що входять до складу цих засобів, у харчових продуктах тваринного походження після закінчення періоду виведення (очікування). Відсутність такої норми в чинному законодавстві на сьогодні призводить до практики неконтрольованого застосування ветеринарних препаратів, а нерідко й самих діючих речовин в умовах українських господарств.

Законопроект передбачає доповнення чинного Закону "Про державний контроль за дотриманням законодавства про харчові продукти, корми, побічні про- дукти тваринного походження, здоров'я та благополуччя тварин" спеціальними положеннями щодо державного контролю за ветеринарними препаратами, діючими речовинами та засобами ветеринарної медицини. Зокрема, передбачається, що виконання заходів, намічених планом державного моніторингу залишкових кількостей ветеринарних препаратів у харчових продуктах тваринного походження, покладається на уповноважені лабораторії, визначені компетентним органом.

У разі виявлення під час державного моніторингу перевищення MRL діючих речовин ветеринарних препаратів у харчових продуктах тваринного походження уповноважена лабораторія зобов'язана негайно повідомити про це компетентний орган. На підставі отриманої інформації про перевищення максимальних меж компетентний орган може організовувати здійснення позапланових заходів державного контролю та інших заходів, передбачених законом, для припинення застосування відповідних ветеринарних препаратів та/або припинення обігу таких харчових продуктів. При цьому запроваджується дієва система санкцій за порушення вимог законодавства про залишки.

Варто зазначити, що в разі очікуваного прийняття вказаного законопроекту до кінця 2020 року, заплановане ним набрання чинності відбудеться за два роки. Протягом цього періоду Україні важливо вдосконалити необхідні процедури та впровадити якісні підзаконні акти, що дозволить повноцінно досягнути європейських стандартів щодо залишків.

На сьогодні, на наш погляд, розвиток вітчизняного законодавства про залишки значно ускладняється через недосконалість інституційної складової. На відміну від $\mathrm{CC}$, де встановлення максимальних меж залишків діючих речовин ветеринарних препаратів у харчових продуктах тваринного походження та процедури реєстрації ветеринарних препаратів переважно зосереджені в рамках одного органу - СМА, в Україні цими питаннями займається два різних компетентних органи: Міністерство охорони здоров'я щодо показників безпечності харчових продуктів та Міністерство економіки й сільськогосподарської політики через підпорядковану йому Держпродспоживслужбу України щодо умов реєстрації та обігу ветеринарних препаратів.

3 урахуванням вищесказаного, на наш погляд, подальше реформування українського законодавства щодо залишків, пов'язане з імплементацією зазначених Регламентів СС, вимагає вирішення таких питань:

- вдосконалення національного інституційного механізму шляхом оптимального розподілу компетенції та налагодження взаємодії між Міністерством охорони здоров'я і Держпродспоживслужбою щодо питань регулювання залишків;

- створення механізму динамічного оновлення MRL відповідно до змін, що приймаються в Свросоюзі, та поступове створення засад для власних наукових оцінок безпечності залишків;

- вирішення питання щодо порядку застосування в Україні висновків СМА щодо діючих речовин, які 
деталізують та пояснюють особливості застосування конкретних показників до різних видів харчової продукції тваринного походження.

- визначення порядку вирішення можливих колізій між стандартами ЄС та Кодексу Аліментаріус щодо залишків.

Окремий блок питань, без вирішення яких імплементація вказаних Регламентів в Україні буде лише формальною, а безпека харчової продукції недосяжною, становлять питання контролю за правильним застосуванням легальних ветеринарних препаратів виробниками тваринницької продукції, а особливо боротьби 3 обігом незареєстрованих ветеринарних препаратів та використанням недозволених ДР.

\section{Висновки}

Таким чином, подальша відсутність в Україні належного правового регулювання залишків загрожує такими наслідками, як посилення резистентності до антибіотиків, унеможливлення лікування людей та тварин від особливо тяжких хвороб, збільшення кількості хронічних захворювань; негативний вплив на навколишнє середовище та значні економічні збитки, спричинені вказаними наслідками. Нагальність та пріоритетність реформи вітчизняного законодавства щодо залишків ветеринарних препаратів у харчовій продукції тваринного походження для продовольчої безпеки України є беззаперечною. На сьогодні вагомим поштовхом для європеїзації відповідного законодавства України стала реалізація Угоди про асоціацію та функціонування зони вільної торгівлі з СС.

У разі успішного завершення імплементації проаналізованих Регламентів СС щодо залишків, така реформа сприятиме підвищенню безпеки вітчизняної харчової продукції, а отже матиме важливі позитивні наслідки не тільки для розвитку торгівлі з СС, а передусім - для продовольчої безпеки держави та захисту здоров'я українських громадян. Лише за таких умов Україна почне давати адекватну відповідь викликам сьогодення та ризикам, що загрожують національній безпеці.

\section{References}

Council Directive 96/23/EC of 29 April 1996 on measures to monitor certain substances and residues thereof in live animals and animal products and repealing Directives 85/358/EEC and 86/469/EEC and Decisions 89/187/EEC and 91/664/EEC. OJ L 125, 23.5.1996, p. 10-32. URL: https:/eurlex.europa.eu/LexUriServ/LexUriServ.do?uri=CONS LEG:1996L0023:20090807:EN:PDF.

Dyrektyva Yevropeiskoho Parlamentu ta Rady pro Kodeks Spivtovarystva shchodo likarskykh zasobiv dlia veterynarnoho zastosuvannia № 2001/82/IeS vid 6 lystopada 2001 roku. Ofitsiinyi visnyk Yevropeiskoho Soiuzu L 311 (in Ukrainian).

Final report of an audit carried out in Ukraine from 05 September 2016 to 16 September 2016 in order to evaluate the control of residues and contaminants in live animals and animal products including controls on veterinary medicinal products. URL: http:/ec.europa.eu/food/audits-analysis/audit_reports/ details.cfm?rep_id=3719.

Kukhtyn, M., Salata, V., Pelenyo, R., Selskyi, V., Horiuk, Y., Boltyk, N., Ulko, L., \& Dobrovolsky, V. (2020). Investigation of zeranol in beef of Ukrainian production and its reduction with various technological processing. Potravinarstvo Slovak Journal of Food Sciences, 14, 95-100. doi: 10.5219/1224.

Nakaz Derzhprodspozhyvsluzhby "Pro zatverdzhennia planu derzhavnoho monitorynhu zalyshkiv veterynarnykh preparativ ta zabrudniuvachiv u zhyvykh tvarynakh i nepereroblenykh kharchovykh produktakh na 2020 rik” vid 05 hrudnia 2019 roku, №1180. URL: https://dpss.gov.ua/bezpechnist-harchovih-produktiv-taveterinarna-medicina/monitoring-zalishkovih-kilkostej (in Ukrainian).

Nakaz Ministerstva okhorony zdorovia Ukrainy "Pro zatverdzhennia Pokaznykiv bezpechnosti kharchovykh produktiv "Maksymalni mezhi (rivni) zalyshkiv diiuchykh rechovyn veterynarnykh preparativ $\mathrm{u}$ kharchovykh produktakh tvarynnoho pokhodzhennia" 23.12.2019 № 2646. Ofitsiinyi visnyk Ukrainy vid 28.01.2020, № 7, stor. 30, stattia 306, kod akta 97725/2020 (in Ukrainian).

Proekt Zakonu pro veterynarnu medytsynu ta blahopoluchchia tvaryn, nomer 3318, data reiestratsii 09.04.2020. URL: http://w1.c1.rada.gov.ua/pls/zweb2/ webproc4_1?pf3511=68554 (in Ukrainian).

Rehlament Yevropeiskoho Parlamentu ta Rady (IeS) № $37 / 2010$ vid 22 hrudnia 2009 r. shchodo maksymalnykh mezh zalyshkiv farmakolohichno aktyvnykh rechovyn ta yikh klasyfikatsii v kharchovykh produktakh tvaryn-noho pokhodzhennia. Ofitsiinyi visnyk Yevropeiskoho Soiuzu L 15/1 (in Ukrainian).

Rehlament Yevropeiskoho Parlamentu ta Rady (IeS) № 470/2009 vid 6 travnia 2009 r., yakym vstanovliuiutsia protsedury Spivtovarystva $\mathrm{z}$ vyznachennia rivniv zalyshkiv farmakolohichno aktyvnykh rechovyn $\mathrm{u}$ kharchovykh produktakh tvarynnoho pokhodzhennia ta skasovuietsia diia Rehlamentu Rady (IeES) № 2377/90 i vnosiat-sia zminy do Dyrektyvy Yevropeiskoho Parlamentu ta Rady 2001/82/IeC i Rehlamentu Yevropeiskoho Parlamentu ta Rady (IeC) № 726/2004. Ofitsiinyi visnyk Yevropeiskoho Soiuzu L 152/11 (in Ukrainian).

Rozporiadzhennia Kabinetu Ministriv Ukrainy vid 24 liutoho 2016 r. № 228-r "Pro skhvalennia Vseokhopliuiuchoi stratehii implementatsii Hlavy IV (Sanitarni ta fitosanitarni zakhody) Rozdilu IV "Torhivlia i pytannia, poviazani z torhivleiu" Uhody pro asotsiatsiiu mizh Ukrainoiu, z odniiei storony, ta Yevropeiskym Soiuzom, Yevropeiskym Spivtovarystvom $\mathrm{z}$ atomnoi enerhii i yikhnimy derzhavamy-chlenamy, z inshoi storony". Uriadovyi kurier vid 06.04.2016 № 65 (in Ukrainian).

Salata, V. (2018). The problem of control of zeranol - a growth promoter of ruminant in beef. Scientific Messenger of LNU of Veterinary Medicine and 
Biotechnologies. Series: Veterinary Sciences, 20(88), 53-55. doi: 10.32718/nvlvet8809.

Uhoda pro asotsiatsiiu mizh Ukrainoiu ta Yevropeiskym Soiuzom i yoho derzhavamy-chlenamy. Ofitsiinyi visnyk Ukrainy vid 26.09.2014, № 75, tom 1, stor. 83, stattia 2125 (in Ukrainian).

V Ukraini rozpochala robotu misiia YeK shchodo otsinky systemy derzhkontroliu z monitorynhu zalyshkiv vetpreparativ $\mathrm{u}$ tvarynakh $\mathrm{i}$ tvarynnytskii produktsii. URL: $\quad$ http://www.consumer.gov.ua/News/344/ V_Ukraini_rozpochala_robotu_misiya_EK_shchodo_ots inki_sistemi_derzhkontrolyu_z_monitoringu_zalishkiv_v etpreparativ_u_tvarinakh_i_tvarinnitskiy_produktsii (in Ukrainian)

Zakon Ukrainy "Pro bezpechnist ta hihiienu kormiv" vid 21.12.2017 № 2264-VIII. Uriadovyi kuryer, 24.01.2018, № 16. URL: https://zakon.rada.gov.ua/laws/show/226419\#Text (in Ukrainian).

Zakon Ukrainy "Pro derzhavnyi kontrol za dotrymanniam zakonodavstva pro kharchovi produkty, kormy, pobichni produkty tvarynnoho pokhodzhennia, zdorovia ta blahopoluchchia tvaryn" vid 18.05.2017 № 2042-VIII. Uriadovyi kurier, 02.08.2017, № 142 .
URL: https://zakon.rada.gov.ua/laws/show/204219\#Text (in Ukrainian).

Zakon Ukrainy "Pro osnovni pryntsypy ta vymohy do bezpechnosti ta yakosti kharchovykh produktiv" vid 23.12.1997 № 771/97-VR. Uriadovyi kurier, 01.10.2014, № 180. URL: https://zakon.rada.gov.ua/ laws/show/771/97-вp\#Text (in Ukrainian).

Zakon Ukrainy "Pro veterynarnu medytsynu" vid 25.06.1992 № 2498-XII. Holos Ukrainy ofitsiine vydannia vid 24.07.1992. URL: https://zakon.rada.gov. ua/laws/show/2498-12\#Text (in Ukrainian).

Zakonu Ukrainy "Pro Zahalnoderzhavnu tsilovu ekonomichnu prohramu provedennia monitorynhu zalyshkiv veterynarnykh preparativ ta zabrudniuiuchykh rechovyn u zhyvykh tvarynakh, produktakh tvarynnoho pokhodzhennia i kormakh, a takozh u kharchovykh produktakh, pidkontrolnykh veterynarnii sluzhbi, na 2010-2015 roky" vid 4 chervnia 2009 roku N 1446-VI. Holos Ukrainy vid 02.07.2009. № 120. URL: https://ips.ligazakon.net/document/ view/t091446?an=2\&ed=2011_11_15 (in Ukrainian). 